\title{
METHYLENETETRAHYDROFOLATE REDUCTASE C677T POLYMORPHISM AND RISK OF COLORECTAL CANCER IN THE MACEDONIAN POPULATION
}

\author{
Matevska $\mathrm{N}^{1 * *}$, Josifovski $\mathrm{T}^{2 * *}$, Kapedanovska $\mathrm{A}^{1}$, Sterjev $\mathrm{Z}^{1}$, \\ Serafimoska $Z^{1}$, Panovski $M^{2}$, Jankulovski $N^{2}$, Petrusevska $N^{3}$, \\ Angelovska $B^{3}$, Petrusevska $\mathrm{G}^{4}$, Suturkova $\mathrm{L}^{1}$, Dimovski AJ ${ }^{1 *}$
}

\begin{abstract}
*Corresponding Author: Aleksandar J. Dimovski, Ph.D., Center for Biomolecular Sciences, Faculty of Pharmacy, University Ss Cyril and Methodius, Skopje 1000, Republic of Macedonia; Tel.: +3892-3217 580; 3119 694; Fax: +389-2-3290 830; 3123 054; e-mail: adimovski@ff.ukim.edu.mk
\end{abstract}

\begin{abstract}
Methylenetetrahydrofolate reductase (MTHFR) regulates the flow of folate groups between DNA synthesis and DNA methylation. A common C677T substitution (Ala222Val) in exon 4 of the MTHFR gene has been linked with the risk of colorectal cancer (CRC). To assess this risk in the Macedonian population, we conducted a case-control study of 413 randomly selected CRC patients and 185 controls without a clinical diagnosis of CRC. We found a statistically significant inverse association between the MTHFR T allele (35.35\% for the patients and $41.35 \%$ for the controls) and the CRC risk

1 Center for Biomolecular Sciences, Faculty of Pharmacy, University of Ss Cyril and Methodius, Skopje, Republic of Macedonia

2 Clinic for Abdominal Surgery, University of Ss Cyril and Methodius, Skopje, Republic of Macedonia

3 Institute of Radiotherapy and Oncology, University of Ss Cyril and Methodius, Skopje, Republic of Macedonia

4 Institute of Pathology, Faculty of Medicine, University Ss Cyril and Methodius, Skopje, Republic of Macedonia

** These two authors contributed equally to the study presented here and should both be considered as first authors.
\end{abstract}

[odds ratio (OR) $0.776 ; 95 \%$ confidence interval (95\% CI) 0.603-0.997; $p=0.047$ ). The prevalence of the MTHFR T allele is lower in patients with advanced CRC (Duke's stage C and D) and with microsatellite instable tumors (MSI+), indicating the inverse association with the CRC aggressiveness and MSI status. This effect seems to be independent of gender, age of onset and localization. We concluded that the MTHFR 677T allele is more likely to have a protective effect on CRC development and progression in the Macedonian population.

Key words: Methylenetetrahydrofolate reductase (MTHFR); C677T polymorphism; Colorectal cancer (CRC)

\section{INTRODUCTION}

Methylenetetrahydrofolate reductase (MTHFR) plays a central role in folate metabolism, regulating the flow of folate groups between two important biosynthetic pathways: DNA synthesis and DNA methylation (Figure 1) [1-4]. Methylenetetrahydrofolate reductase catalyzes the irreversible reduction of 5,10-methylenetetrahydrolate (5,10-methyleneTHF) to 5-methyltetrahydrofolate (5-methylTHF), the main circulating form of folate in plasma and provides methyl groups for de novo synthesis of methionine, the precursor of S-adenosylmethionine (SAM). S- 


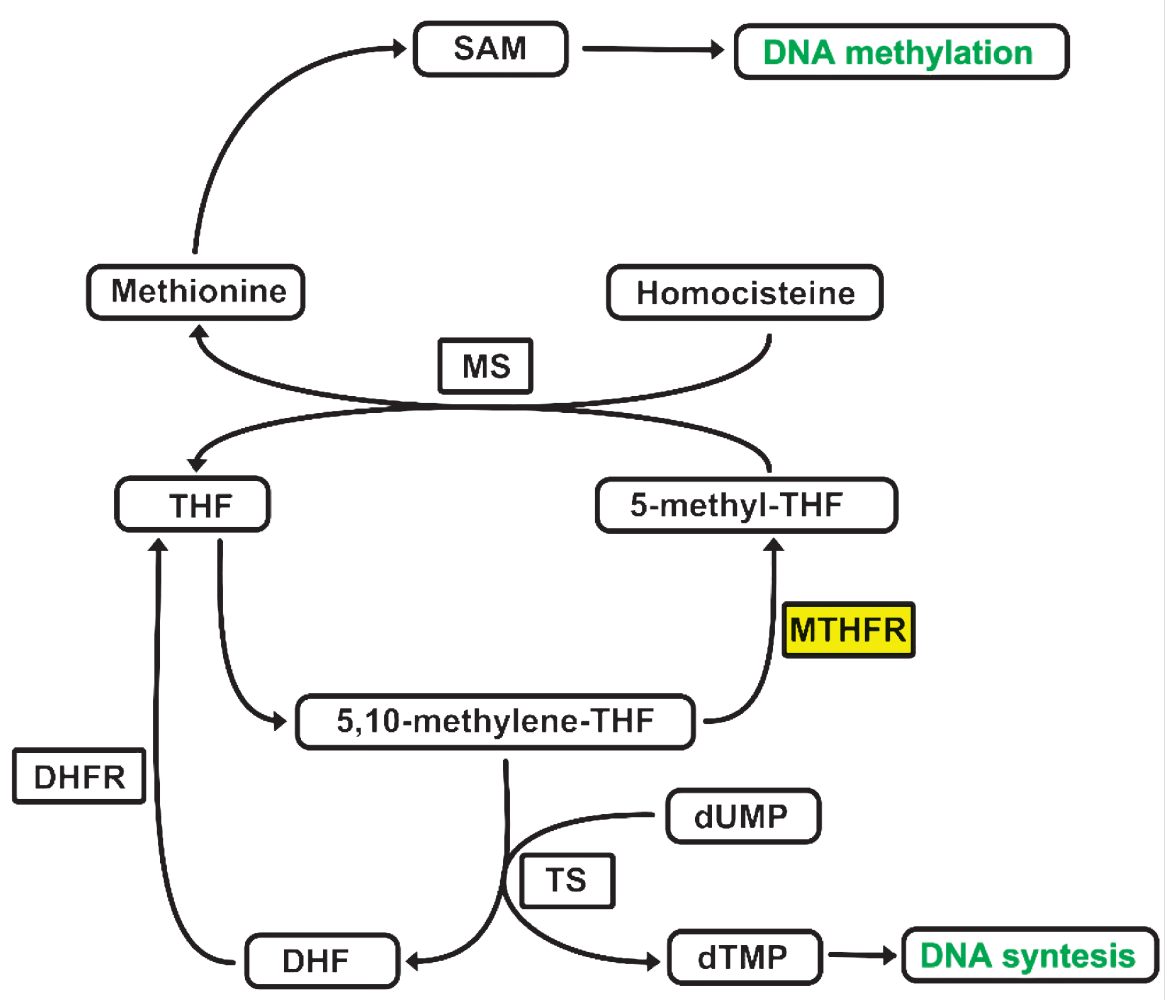

Figure 1. Schematic presentation of folate metabolism in relation to DNA methylation and thymidylate synthesis. THF: tetrahydrofolate; DHF: dihydrofolate; DHFR: dihydrofolate reductase; MS: methionine synthase; TS: thymidylate synthase; dUMP: deoxyuridine monophosphate (deoxyuridylate); dTMP: deoxythymidine monophosphate (deoxythymidylate); SAM: S-adenosylmethionine.

adenosylmethionine is the universal methyl-group donor for methylation of a wide variety of biological substrates, including DNA methylation, and may thereby contribute to carcinogenesis [5-9]. The substrate for MTHFR, 5,10-methyleneTHF, is an intracellular form of folate required for the conversion of deoxyuridylate (dUMP) to deoxythymidylate (dTMP) and is therefore vital for DNA synthesis. Depletion of this form of folate may produce deoxynucleotide pool imbalances, massive uracil incorporation into DNA and double-strand chromosome breaks, a feature commonly seen in colorectal cancer $[10,11]$.

The MTHFR gene is located on chromosome 1p36.3. A common C677T substitution (Ala222Val) in exon 4 has been linked with the risk of numerous diseases, including cancer [12]. The variant enzyme is associated with a reduced enzyme activity and increased thermolability $[12,13]$. Individuals homozygous for the variant allele (677TT) have approximate- ly $30 \%$, whereas heterozygotes (677CT) have $65 \%$ of the normal enzyme activity. Compared with the wildtype, heterozygotes and TT homozygotes have lower plasma folate levels, raised homocysteine levels and reduced global DNA methylation in peripheral leucocytes [13-16].

Numerous studies have been made about the association between the C677T polymorphism and susceptibility to colorectal cancer (CRC). The majority point to a lower prevalence of CRC among individuals with the 677TT genotype [14,18-24], especially at high levels of folate intake [2,17]. However, some studies have implicated the $\mathrm{C}$ allele with increased CRC risk [25-27], while others have attributed no significant value to any allele of the C677T polymorphism $[28,29]$. Ethnicity, lifestyle, and pattern of diet may have introduced variability into different studies. To assess the MTHFR C677T polymorphism as a risk factor for CRC in the Macedonian population, we 
conducted a case-control study of 413 randomly selected CRC patients and 185 controls without a clinical diagnosis of CRC.

\section{MATERIALS AND METHODS}

A total of 413 randomly selected patients with CRC and 185 control subjects from the Republic of Macedonia were recruited from the University Clinic of Abdominal Surgery and the Institute of Radiotherapy and Oncology in Skopje, between January 2006 and October 2008 (Table 1). Written informed consent was obtained from all participants of the study before the collection of the specimens. A questionnaire was used to elicit detailed information on demographic and clinical variables, prior disease history and family history of cancer. The average age of the patients was $60.27 \pm 11.08$ years. The control subjects consisted of 94 adults (average age $74.52 \pm 10.46$ ) and 91 newborns without any history of malignant disease. Since both control groups showed a similar genotype distribution, the results were integrated in further calculations.

Genomic DNA was isolated from peripheral blood and tumors using Proteinase $\mathrm{K}$ digestion/ phenol-chloroform extraction and ethanol precipitation. The MTHFR C677T polymorphism (rs1801133) was genotyped by real-time polymerase chain reaction (PCR) (MxPro 3005P, Stratagene, La Jolla, CA, USA) using the TaqMan SNP genotyping assay according to the manufacturer's instructions (Applied Biosystems, Foster City, CA, USA).

Descriptive comparisons [i.e., means, standard deviation (SD), frequencies as percentages] of CRC patients and controls were conducted using a chisquare test for categorical variables and analysis of covariance for continuous variables. Logistic regression was used to calculate odds ratios (ORs) and corresponding $95 \%$ confidential intervals $(95 \% \mathrm{CI})$. To examine separate and combined effects of the MTHFR genotype and certain risk factors, stratified analyses were conducted.

Table 1. General characteristics of the colorectal cancer patients and controls

\begin{tabular}{|c|c|c|}
\hline & CRC Group: $n(\%)$ & Control Group : $n$ (\%) \\
\hline Total number of subjects & 413 & 185 \\
\hline $\begin{array}{l}\text { Gender: } \\
\text { - males } \\
\text { - } \quad \text { females }\end{array}$ & $\begin{array}{l}238(57.35) \\
177(42.65)\end{array}$ & $\begin{array}{c}81(43.78) \\
104(56.22)\end{array}$ \\
\hline $\begin{array}{l}\text { Age (years): } \\
\text { - } \text { mean } \pm \text { SD } \\
\text { - } \text { range }\end{array}$ & $\begin{array}{c}60.27 \pm 11.08 \\
15-88\end{array}$ & \\
\hline $\begin{array}{l}\text { Tumor site: } \\
\text { - } \quad \text { proximal } \\
\text { - distal }\end{array}$ & $\begin{array}{l}118(28.57) \\
295(71.43)\end{array}$ & \\
\hline 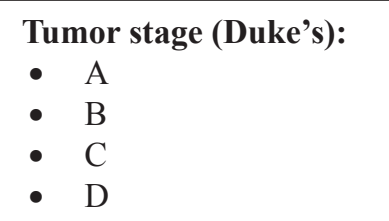 & $\begin{array}{c}33(7.99) \\
181(43.82) \\
163(39.47) \\
36(8.72)\end{array}$ & \\
\hline $\begin{array}{ll}\text { MSI status }^{\text {b }} \\
\text { - } & \text { MSI+ } \\
- & \text { MSI- }\end{array}$ & $\begin{array}{c}30(11.81) \\
224(88.19)\end{array}$ & \\
\hline
\end{tabular}

CRC: colorectal cancer; MSI: microsatellite instability.

a Ninety-one adults (mean \pm SD: $74.52 \pm 10.46$; range 48-97) and 94 newborns.

${ }^{\mathrm{b}}$ Determined for 254 subjects. 


\section{RESULTS}

The characteristics of the study participants are presented in Table 1. Allele and genotype frequencies of MTHFR C677T polymorphism are presented in Table 2. No significant deviations from HardyWeinberg equilibrium were noted in either group. We found a statistically significant inverse association between the MTHFR T allele (35.35\% for CRC patients and $41.35 \%$ for controls) and CRC risk (OR 0.776 ; 95\% CI 0.603-0.997; $p=0.047)$. Prevalence of the variant allele $(677 \mathrm{~T})$ within this population
95\% CI 0.442-1.134; $p=0.149$ and OD 0.729; $95 \%$ CI $0.729 ; p=0.085$ respectively), although there was a trend for significance towards the dominant model.

We stratified the subjects according to gender, age, and tumor stage, localization and microsatellite instability (MSI) status. Table 3 provides the ORs for the association between these variables and $\mathrm{CRC}$ risk (in all calculations the $\mathrm{C}$ allele was used as a reference). The results point towards a protective role of the MTHFR T allele in the progression of CRC, as shown with the lower prevalence of

Table 2. Association between MTHFR genotype and colorectal cancer risk

\begin{tabular}{|c|c|c|c|c|c|}
\hline $\begin{array}{l}\text { MTHFR } \\
\text { Genotype }\end{array}$ & $\begin{array}{c}\text { CRC Patients } \\
(n)(\%)\end{array}$ & $\begin{array}{c}\text { Controls } \\
(n)(\%)\end{array}$ & Odds Ratios & $\begin{array}{c}\text { 95\% Confidence } \\
\text { Interval }\end{array}$ & $p$ Value \\
\hline
\end{tabular}

Genotype Frequencies

\begin{tabular}{|l|c|c|c|c|c|}
\hline CC & $\mathbf{1 7 6}(\mathbf{4 2 . 6 1 )}$ & $\mathbf{6 5} \mathbf{( 3 5 . 1 3 )}$ & 1.00 & Reference & \\
\hline CT & $\mathbf{1 8 2}(\mathbf{4 4 . 0 7 )}$ & $\mathbf{8 7}(\mathbf{4 7 . 0 3}$ & 0.773 & $0.527-1.132$ & 0.185 \\
\hline TT & $\mathbf{5 5 ( 1 3 . 3 2 )}$ & $\mathbf{3 3 ( 1 7 . 8 4 )}$ & 0.616 & $0.367-1.032$ & 0.064 \\
\hline CC and CT & $358(88.68)$ & $152(82.16)$ & 1.00 & Reference & \\
\hline TT & $55(13.32)$ & $33(17.84)$ & 0.708 & $0.442-1.134$ & 0.149 \\
\hline CC & $176(42.61)$ & $65(35.13)$ & 1.00 & Reference & \\
\hline CT and TT & $237(57.39)$ & $120(64.87)$ & 0.729 & $0.509-1.025$ & 0.805 \\
\hline
\end{tabular}

\section{Allele Frequencies}

\begin{tabular}{|l|c|c|c|c|c|}
\hline $\mathbf{C}$ & $534(64.65)$ & $217(58.65)$ & 1.00 & Reference & \\
\hline $\mathbf{T}$ & $292(35.35)$ & $153(41.35)$ & 0.776 & $0.603-0.997$ & 0.047 \\
\hline
\end{tabular}

did not differ significantly from the prevalences reported in other Caucasian populations (30-35\%) $[30,31]$.

We observed a difference in overall genotype distribution between the CRC patients and controls (CC 42.61\%; CT 44.07\%; TT 13.32\% for CRC patients and CC $35.13 \%$; CT $47.03 \%$; TT $17.84 \%$ for controls) even though it did not reach statistical significance ( $p=0.064 \mathrm{TT}$; $p=0.185 \mathrm{CT}$; CC as reference). The MTHFR 677T allele was not associated with CRC either in a recessive (TT vs. CT $+\mathrm{CC}$ ) or in a dominant (TT + CT vs. CC) model (OD 0.708; the $\mathrm{T}$ allele in patients with aggressive CRC (OD $0.682 ; 95 \%$ CI $0.484-0.961 ; p=0.028$ for Duke's C and OR $0.575 ; 95 \%$ CI $0.305-1.085 ; p=0.084$ for Duke's D). Although with borderline significance, we found a similar inverse association between the MTHFR 677T allele and MSI status (OD 0.561; 95\% CI 0.308-1.020; $p=0.055$ ).

\section{DISCUSSION}

The results from our study suggest that the $\mathrm{T}$ allele is more likely to have a protective effect in 
Table 3. Association between MTHFR and colorectal cancer risk after stratification by clinicopathological parameters

\begin{tabular}{|c|c|c|c|}
\hline & Odds Ratios & 95\% Confidence Intervals & $p$ Value \\
\hline $\begin{array}{l}\text { Gender: } \\
\text { - } \quad \text { males } \\
\text { - } \quad \text { females }\end{array}$ & $\begin{array}{l}0.835 \\
0.700\end{array}$ & $\begin{array}{l}0.580-1.203 \\
0.492-0.998\end{array}$ & $\begin{array}{l}0.333 \\
0.048\end{array}$ \\
\hline $\begin{array}{l}\text { Age of onset: } \\
\begin{array}{l}-\quad 60 \text { years } \\
-\quad<60 \text { years }\end{array}\end{array}$ & $\begin{array}{l}0.812 \\
0.799\end{array}$ & $\begin{array}{l}0.604-1.092 \\
0.603-1.059\end{array}$ & $\begin{array}{l}0.168 \\
0.117\end{array}$ \\
\hline $\begin{array}{l}\text { Tumor site: } \\
\text { - } \quad \text { proximal } \\
\text { - } \quad \text { distal }\end{array}$ & $\begin{array}{l}0.828 \\
0.849\end{array}$ & $\begin{array}{l}0.592-1.159 \\
0.651-1.108\end{array}$ & $\begin{array}{l}0.270 \\
0.228\end{array}$ \\
\hline \begin{tabular}{ll}
\multicolumn{2}{l}{ Tumor stage (Duke's): } \\
$-\quad \mathrm{A}$ \\
- & $\mathrm{B}$ \\
- & $\mathrm{C}$ \\
- & $\mathrm{D}$
\end{tabular} & $\begin{array}{l}1.114 \\
0.830 \\
0.682 \\
0.575\end{array}$ & $\begin{array}{l}0.614-2.021 \\
0.599-1.150 \\
0.484-0.961 \\
0.305-1.085\end{array}$ & $\begin{array}{l}0.721 \\
0.263 \\
0.028 \\
0.084\end{array}$ \\
\hline $\begin{array}{ll}\text { MSI }^{\text {status }}{ }^{\mathbf{b}} \text { : } \\
- & \text { MSI+ } \\
\bullet & \text { MSI- }\end{array}$ & $\begin{array}{l}0.561 \\
0.843\end{array}$ & $\begin{array}{l}0.308-1.020 \\
0.636-1.117\end{array}$ & $\begin{array}{l}0.055 \\
0.234\end{array}$ \\
\hline
\end{tabular}

CRC: colorectal cancer; MSI: microsatellite instability.

Odds ratio: $\mathrm{C}$ allele is used as reference.

CRC development in the Macedonian population. The prevalence of the MTHFR T allele was lower in patients with advanced CRC (Duke's stages $\mathrm{C}$ and D) and with microsatellite instable tumors (MSI+), indicating an inverse association with the $\mathrm{CRC}$ aggressiveness and MSI status. This effect seemed to be independent of gender, age of onset and localization since there was no difference after the stratification regarding these variables. Methylenetetrahydrofolate reductase regenerates the methionine from homocysteine, to maintain the supply of SAM for diverse methylation reactions of DNA, RNA, proteins and lipids. Total plasma homocysteine (tHcy) is a functional indicator of MTHFR activity and is correlated with the possession of the thermolabile form of the enzyme [32] and is inversely associated with DNA methylation [33]. DNA hypomethylation, particularly within promoter regions, could potentially reverse methyl-mediated silencing of oncogenes. Because of all of these, it could be expected that MTHFR 677TT is likely to increase the risk of CRC. Although some studies support this hypothesis [25-27], the majority of the studies, as well as two recent meta-analyses, have found a reduced risk of CRC associated with the MTHFR C677T homozygous variant (TT) genotype [14,18$24,34,35$ ] that agree with our results (Figure 2). An alternative to the DNA hypomethylation hypothesis to account for the reduced risk associated with the C677T polymorphism has been proposed [18]. The higher activity of the wild-type enzyme may reduce the availability of 5,10-methyleneTHF for synthesis of dTMP from dUMP. Low erythrocyte folate levels $(<140 \mathrm{ng} / \mathrm{mL})$ were associated with increased frequency of DNA double-strand breaks as a consequence of the mis-incorporation of uracil.[36] The TT genotype would slow down the conversion of 5,10-methyleneTHF to 5-methylTHF and close 


\begin{tabular}{|c|c|c|c|c|c|c|}
\hline \multirow[t]{2}{*}{ Studyname } & Ethnicity & \multicolumn{2}{|c|}{ T allele/ Total } & \multicolumn{3}{|l|}{ Odds ratio and $95 \% \mathrm{Cl}$} \\
\hline & & Cases & Controls & & $\begin{array}{l}\text { Odds } \\
\text { ratio }\end{array}$ & p-Value \\
\hline Chenet al. 1996 & Caucasian (US) & $90 / 288$ & $431 / 1254$ & & 0,868 & 0,313 \\
\hline Maet al. 1997 & Unknown (US) & $128 / 404$ & $230 / 652$ & 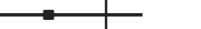 & 0,851 & 0,231 \\
\hline Slatteryet al. 1999 & Caucasian, African-American, Hispanic (US) & $933 / 2934$ & $1201 / 3641$ & & 0,947 & 0,307 \\
\hline Keluet al. 2002 & Caucasian, African-American (US) & $188 / 616$ & $325 / 1078$ & & 1,018 & 0,873 \\
\hline Le Marchand et al. 2002 & Caucasian (US) & $102 / 298$ & $129 / 342$ & & 0,859 & 0,359 \\
\hline Sharnon et al. 2002 & Caucasian (Australia) & $307 / 1002$ & $788 / 2414$ & - & 0,911 & 0,253 \\
\hline Plaschkeet al. 2003 & Caucasian (Germany) & $188 / 574$ & $235 / 692$ & & 0,947 & 0,650 \\
\hline Toffoli et al. 2003 & Caucasian (Italy) & $221 / 552$ & $252 / 558$ & & 0,811 & 0,084 \\
\hline Ulviket al. 2004 & Unknown (Norway) & $1213 / 4318$ & $1310 / 4380$ & & 0,916 & 0,062 \\
\hline Yinet al. 2004 & Asian (Japan) & $500 / 1370$ & $633 / 1556$ & & 0,838 & 0,020 \\
\hline Wang et al. 2006 & Asian (India) & $47 / 604$ & $36 / 582$ & & 1,280 & 0,282 \\
\hline Cheng et al. 2007 & Asian (Taiven) & $134 / 390$ & $119 / 390$ & & 1,192 & 0,251 \\
\hline Limaet al. 2007 & Caucasian, African-American (Brazil) & $76 / 204$ & $187 / 600$ & & 1,311 & 0,110 \\
\hline \multirow[t]{3}{*}{ Our study } & Caucasian (Macedonia) & $292 / 826$ & $153 / 370$ & & 0,776 & 0,047 \\
\hline & & & & & 0,921 & 0,001 \\
\hline & & & & 1 & & \\
\hline
\end{tabular}

Figure 2. Overall meta analysis for the C677T polymorphism (T vs. C allele) in colorectal cancer. Point estimates of the odds ratios for each study and the accompanying $95 \%$ confidence interval values obtained with a fixed effects model are shown.

this avenue for DNA damage [31]. Therefore, the MTHFR C677T polymorphism would modify the $\mathrm{CRC}$ risk and $\mathrm{CRC}$ advancement by influencing the availability of 5,10-methyleneTHF for DNA synthesis and repair rather than through DNA methylation. The conflicting results from different studies (Figure 2), may result from dissimilarity in lifestyle and dietary habits in different populations (e.g., diet rich or low in folate, alcohol consumption), and from polymorphisms in genes encoding for other enzymes (Dihydrofolate reductase; Methionine synthase; Thymidylate synthase or others), interconnected in folate metabolism.

The inverse association between the MTHFR $677 \mathrm{~T}$ allele and the MSI+ that we observed, can be explained by the DNA hypomethylation hypothesis. The lower enzyme activity in homozygotes for the variant allele (677TT) could lead to reduced epigenetic silencing of the mismatch repair (MMR) genes, this being the main reason for MSI in sporadic $\mathrm{CRC}$.

In conclusion, our results suggest that the MTHFR 677T allele is more likely to have a protective effect in CRC development and progression in the Macedonian population, and support previous findings of an inverse association of the MTHFR 677T allele with CRC. Knowledge of the interac- tion between folate intake and the MTHFR polymorphisms could be useful in elucidating the role of the MTHFR polymorphisms in colorectal carcinogenesis.

\section{REFERENCES}

1. Kim YI. Folate and carcinogenesis: evidence, mechanisms, and implications. J Nutr Biochem 1999; 10(2): 66-88.

2. Choi SW, Mason JB. Folate status: effects on pathways of colorectal carcinogenesis. J Nutr 2002; 132(Suppl. 8): 2413S-2418S.

3. Ryan BM, Molloy AM, McManus R, Arfin Q, Kelleher D, Scott JM, Weir DG. The Methylenetetrahydrofolate reductase (MTHFR) gene in colorectal cancer: role in tumor development and significance of allelic loss in tumor progression. Int J Gastrointest Cancer 2001; 30(3): 105-111.

4. Little J, Sharp L. Colorectal neoplasia and genetic polymorphisms associated with folate metabolism. Eur J Cancer Prev 2002; 11(1): 105-110.

5. Das PM, Singal R. DNA methylation and cancer. J Clin Oncol 2004; 22(22): 4632-4642.

6. Jones PA, Baylin SB. The fundamental role of epigenetic events in cancer. Nat Rev Genet 2002; 3(6): 415-428. 
7. Eden A, Gaudet F, Waghmare A, Jaenisch R. Chromosomal instability and tumors promoted by DNA hypomethylation. Science 2003; 300(5618): 455.

8. Herman JG, Baylin SB. Gene silencing in cancer in association with promoter hypermethylation. N Engl J Med 2003; 349(21): 2042-2054.

9. Esteller M. Aberrant DNA methylation as a cancer-inducing mechanism. Annu Rev Pharmacol Toxicol 2005; 45: 629-656.

10. Duthie SJ, Narayanan S, Blum S, Piric L, Brand G. Folate deficiency in vitro induces uracil misincorporation and DNA hypomethylation and inhibits DNA excision repair in immortalized normal colon epithelial cells. Nutr Cancer 2000; 37(2): 245-251.

11. Eichholzer M, Lüthy F, Moser U, Fowler B. Folate and the risk of colorectal, breast and cervix cancer: the epidemiological evidence. Swiss Med Wkly 2001; 131(37-38): 539-549.

12. Ueland PM, Hustad S, Schneede J, Refsum $\mathrm{H}$, Vollset SE. Biological and clinical implications of the MTHFR C677T polymorphism. Trends Pharmacol Sci 2001; 22(4): 195-201.

13. Frosst P, Blom HJ, Milos R, Goyette $P$ Sheppard CA, Matthews RG, Boers GJ, den Heijer M, Kluijtmans LA, van den Heuvel LP. A candidate genetic risk factor for vascular disease: a common mutation in methylenetetrahydrofolate reductase. Nat Genet 1995; 10(1): 111-113.

14. Ma J, Stampfer MJ, Giovannucci E, Artigas C, Hunter DJ, Fuchs C, Willet WC, Selhub J, Hennekens $\mathrm{CH}$, Rozen R. Methylenetetrahydrofolate reductase polymorphism, dietary interactions, and risk of colorectal cancer. Cancer Res 1997; 57(6): 1098-1102.

15. Molloy AM, Daly S, Mills JL, Kirke PN, Whitehead AS, Ramsbottom D, Conley MR, Weir DG, Scott JM. Thermolable variant of 5,10-methylene-tetrahydrofolate reductase associated with low red-cell folates: implications for folate intake recommendations. Lancet 1997; 349(9065): 15911593.

16. Stern L, Mason J, Selhub J, Choi SW. Genomic DNA hypomethylation, a characteristic of most cancers, is present in peripheral leukocytes of individuals who are homozygous for the C677T polymorphism in the methylenetetrahydrofolate re- ductase gene. Cancer Epidemiol Biomarkers Prev 2000; 9(8): 849-853.

17. Sharp L, Little J. Polymorphisms in genes involved in folate metabolism and colorectal neoplasia: a HuGE Review. Am J Epidemiol 2004; 159:423-443.

18. Chen J, Giovannucci E, Kelsey K, Rimm EB, Stampfer MJ, Colditz GA, Spiegelman D, Willett WC, Hunter DJ A. Methylenetetrahydrofolate reductase polymorphism and the risk of colorectal cancer. Cancer Res 1996; 56(21): 4862-4864.

19. Slattery ML, Potter JD, Samowitz W, Schaffer D, Leppert M. Methylenetetrahydrofolate reductase, diet, and risk of colon cancer. Cancer Epidemiol Biomarkers Prev 1999; 8(6): 513-518.

20. Le Marchand L, Donlon T, Hankin JH, Kolonel LN, Wilkens LR, Seifried A. B-vitamin intake, metabolic genes, and colorectal cancer risk (United States). Cancer Causes Control 2002; 13(3): 239-248.

21. Shannon B, Gnanasampanthan S, Beilby J, Iacopetta B. A polymorphism in the methylenetetrahydrofolate reductase gene predisposes to colorectal cancers with microsatellite instability. Gut 2002; 50(4): 520-524.

22. Toffoli G, Gafa R, Russo A, Lanza G, Dolcetti R, Sartor F, Libra M, Viel A, Boiocchi M. Methylenetetrahydrofolate reductase $677 \mathrm{C} \rightarrow$ T polymorphism and risk of proximal colon cancer in north Italy. Clin Cancer Res 2003; 9(2): 743-748.

23. Ulvik A, Vollset SE, Hansen S, Gislefoss $\mathrm{R}$, Jellum E, Ueland PM. Colorectal cancer and the methylenetetrahydrofolate reductase $677 \mathrm{C} \rightarrow \mathrm{T}$ and methionine synthase $2756 \mathrm{~A} \rightarrow \mathrm{G}$ polymorphisms: a study of 2,168 case-control pairs from the JANUS cohort. Cancer Epidemiol Biomarkers Prev 2004; 13(12): 2175-2180.

24. Yin G, Kono S, Toyomura K, Hagiwara T, Nagano J, Mizoue T, Mibu R, Tanaka M, Kakeji Y, Maehara Y, Okamura T, Ikejiri K, Futami K, Yasunami Y, Maekawa T, Takenaka K, Ichimiya $\mathrm{H}$, Imaizumi N. Methylenetetrahydrofolate reductase C677T and A1298C polymorphisms and colorectal cancer: the Fukuoka Colorectal Cancer Study. Cancer Sci 2004; 95(11): 908-913.

25. Wang J, Gajalakshmi V, Jiang J, Kuriki K, Suzuki S, Nagaya T, Nakamura S, Akasaka S, Ishikawa $\mathrm{H}$, Tokudome $\mathrm{S}$. Associations between 5,10-methylenetetrahydrofolate reductase codon 
677 and 1298 genetic polymorphisms and environmental factors with reference to susceptibility to colorectal cancer: a case-control study in an Indian population. Int J Cancer 2006; 118(4): 991-997.

26. Chang SC, Lin PC, Lin JK, Yang SH, Wang HS, Li AF. Role of MTHFR polymorphisms and folate levels in different phenotypes of sporadic colorectal cancers. Int J Colorectal Dis 2007; 22(5): 483-489.

27. Lima CS, Nascimento H, Bonadia LC, Teori MT, Coy CS, Góes JR, Costa FF, Bertuzzo CS. Polymorphisms in methylenetetrahydrofolate reductase gene (MTHFR) and the age of onset of sporadic colorectal adenocarcinoma. Int J Colorectal Dis 2007; 22(7): 757-763.

28. Keku T, Millikan R, Worley K, Winkel S, Eaton A, Biscocho L, Martin C, Sandler R. 5,10-Methylenetetrahydrofolate reductase codon 677 and 1298 polymorphisms and colon cancer in African Americans and whites. Cancer Epidemiol Biomarkers Prev 2002; 11(12): 1611-1621.

29. Plaschke J, Schwanebeck U, Pistorius S, Saeger HD, Schackert HK. Methylenetetrahydrofolate reductase polymorphisms and risk of sporadic and hereditary colorectal cancer with or without microsatellite instability. Cancer Lett 2003; 191(2): 179-185.

30. Kono S, Chen K. Genetic polymorphisms of methylenetetrahydrofolate reductase and colorectal cancer and adenoma. Cancer Sci. 2005; 96(9):535-542
31. Brockton NT. Localized depletion: the key to colorectal cancer risk mediated by MTHFR genotype and folate? Cancer Causes Control. 2006; 17(8): 1005-1016.

32. Frosst P, Blom HJ, Milos R, Goyette P, Sheppard CA, Matthews RG, Boers GJ, den Heijer M, Kluijtmans LA, van den Heuvel LP. A candidate genetic risk factor for vascular disease: a common mutation in methylenetetrahydrofolate reductase. Nat Genet 1995; 10(1): 111-113.

33. Yi P, Melnyk S, Pogribna M, Pogribny IP, Hine RJ, James SJ. Increase in plasma homocysteine associated with parallel increases in plasma S-adenosylhomocysteine and lymphocyte DNA hypomethylation. J Biol Chem 2000; 275(38): 2931829323.

34. Hubner RA, Houlston RS. MTHFR C677T and colorectal cancer risk: A meta-analysis of 25 populations. Int J Cancer 2007; 120(5): 10271035.

35. Huang Y, Han S, Li Y, Mao Y, Xie Y. Different roles of MTHFR C677T and A1298C polymorphisms in colorectal adenoma and colorectal cancer: a meta-analysis. J Hum Genet. 2007; 52(1): 73-85.

36. Dianov GL, Timchenko TV, Sinitsina OI, Kuzminov AV, Medvedev OA, Salganik RI. Repair of uracil residues closely spaced on the opposite strands of plasmid DNA results in double-strand break and deletion formation. Mol Gen Genet 1991; 225(3): 448-452. 